\title{
ARSENATE TOXICITY FOR WHEAT AND LETTUCE IN SIX CHINESE SOILS WITH DIFFERENT PROPERTIES
}

\author{
Qing Cao, *† Qin-Hong Hu, Cristoph Baisch, $\$$ Sardar Khan, $\|$ and Yong-Guan Zhu† \\ $\dagger$ Research Center for Eco-environmental Sciences, Chinese Academy of Sciences, Beijing 100085, People's Republic of China \\ tDepartment of Earth and Environmental Sciences, University of Texas, Arlington, Texas 76019, USA \\ $\S$ Faculty of Geosciences, Eberhard Karls University, Tübingen 72074, Germany \\ IIDepartment of Environmental Sciences, University of Peshawar, Peshawar 25120, Pakistan
}

(Received 30 December 2008; Accepted 12 April 2009)

\begin{abstract}
To assess soil arsenic (As, in the form of arsenate) toxicity to plants, 6-d root elongation tests on wheat (Triticum aestivum L.) and lettuce (Lactuca sativa) were conducted in six Chinese soils freshly spiked with As. Plants were treated with 7 or 10 levels of As to establish concentration-effect curves. Median effective concentration and 10\% effective concentration values were derived with regression analysis to measure As toxic potencies, and no-observed-effect concentration was determined by comparison with a control to elucidate thresholds of As to the two plant species. The median effective concentration values for As varied from 159 to $683 \mathrm{mg} / \mathrm{kg}$ for wheat and 59 to $426 \mathrm{mg} / \mathrm{kg}$ for lettuce, and the $10 \%$ effective concentration values varied from 79 to $270 \mathrm{mg} / \mathrm{kg}$ for wheat and 20 to $156 \mathrm{mg} / \mathrm{kg}$ for lettuce. The result suggests that lettuce is a more sensitive species for monitoring soil As contamination. With the same level of As spiked, soil toxicity for a plant showed a tendency of fluvoaquic soil toward red soil or black soil toward paddy soil. The phytotoxicity of As was negatively correlated with soil amorphous iron content extracted with ammonium oxalate. The overall results from the present work illustrate the necessity of considering soil properties in assessing soil As contamination.
\end{abstract}

Keywords-Arsenate toxicity Root elongation Median effective concentration Soil properties

\section{INTRODUCTION}

Widespread arsenic (As) contamination of soil is a global issue of increasing concern. Higher soil As levels may be geogenic in origin. Human activities such as mining, coal burning, contaminated water irrigation, and antibiotic chemical application have also elevated As concentration in soils. Through the soil-plant-human continuum, higher As levels are jeopardizing the health of tens of millions of Americans and hundreds of millions of Asians in contaminated areas [12], with problems such as skin and circulatory systems diseases and cancer risk [3]. Soil As contamination is also serious in some areas of China, affecting at least 3 million people [2]. An investigation performed in Chenzhou, southern China, showed $30 \%$ of this area was contaminated with As in the range of 11 to $1,217 \mathrm{mg} / \mathrm{kg}$, and most of the As concentrations in rice grain samples exceed $1.0 \mathrm{mg} / \mathrm{kg}$ [4], www.atsdr.cdc.gov/toxprofiles/ tp2.html.

Elevated As concentrations could hamper plant growth in the contaminated soil. Phytotoxicity of As has been well documented; this includes morphological change (e.g., wilting, chlorosis, browning, and dehydration), growth inhibition, disruption of metabolism (e.g., enzymes and phytochelatins [5]) and energy flow, induction of genotoxic damages, inhibition of the DNA repair system [6], and even mortality. To protect the ecosystem, maximum contaminant levels for As were promulgated in many countries. For example, the maximum allowable level of As for oral intake was set at $0.3 \mu \mathrm{g} \mathrm{kg}^{-1} \mathrm{~d}^{-1}$ by the U.S. Environmental Protection Agency [7], which also adjusted a new As standard for drinking water

* To whom correspondence may be addressed (qingcao@rcees.ac.cn).

Published on the Web 4/20/2009. down to $0.01 \mathrm{mg} / \mathrm{L}$ [8]; this is the same level recommended by the World Health Organization [9]. In England, the guideline value for soil As in the residential land is $20 \mathrm{mg} / \mathrm{kg}$ [10]. The Chinese national standard for As was set according to different soil $\mathrm{pH}$ values $(<6.5,6.5-7.5$, and $>7.5)$ and land use, namely, 30,25 , and $20 \mathrm{mg} / \mathrm{kg}$ for paddy soil and 40,30 , and $25 \mathrm{mg} / \mathrm{kg}$ for upland soil, respectively. However, it is not reasonable to assess all sites with a uniform standard. Furthermore, $\mathrm{pH}$ is not the only property that may affect As toxicity.

Soil ecotoxicological evaluations are the basis of setting allowable levels of contaminant, as well as main factors of environmental management and remediation assessment. Standardized toxicological tests have been developed with test organisms, including the soil-dwelling invertebrate springtails (Collembola) [11], earthworms [12-13] and potworms (Enchytraeus sp.) [14-15], microorganisms (capable of nitrogen or carbon transformation) [16-17], and plants [18]. However, experimental results may vary from site to site for Ascontaminated soil, so it is essential to develop models to predict As toxicity based on soil basic parameters.

Variations of As toxicity in the soil-plant system have been found to be related to the plant species [19-20], duration of aging and exposure [21], oxidation states, and particularly physical properties of soil [22]. Currently, soil properties such as $\mathrm{pH}$, clay, iron, and organic matter contents can be regarded as important in determining the speciation and bioavailability of As in soils and consequently in affecting As toxicity [23]. This variation, which is site specific, needs to be taken into account during the decision-making processes of environmental risk assessment and remediation.

Considering soil properties would make the risk assessment of contaminated soil more realistic. Furthermore, delineation of principal factors that affect As toxicity provides informa- 
Table 1. Major physicochemical properties of six Chinese soils

\begin{tabular}{|c|c|c|c|c|c|c|c|c|c|c|}
\hline \multirow[b]{2}{*}{ Type } & \multirow{2}{*}{$\frac{\mathrm{pH}}{\left(\mathrm{CaCl}_{2}\right)}$} & \multirow{2}{*}{$\begin{array}{l}\text { Organic } \\
\text { matter } \\
(\%)\end{array}$} & \multirow{2}{*}{$\begin{array}{l}\mathrm{CaCO}_{3} \\
(\%)\end{array}$} & \multirow{2}{*}{$\begin{array}{l}\text { Cation exchange } \\
\text { capacity } \\
(\mathrm{cmol} / \mathrm{kg})\end{array}$} & \multirow{2}{*}{$\begin{array}{l}\text { Clay } \\
(\%)\end{array}$} & \multirow{2}{*}{$\begin{array}{l}\text { Total As } \\
(\mathrm{mg} / \mathrm{kg})\end{array}$} & \multirow{2}{*}{$\begin{array}{l}\text { Total Fe } \\
(\mathrm{g} / \mathrm{kg})\end{array}$} & \multicolumn{3}{|c|}{$\begin{array}{l}\text { Ammonium oxalate } \\
\text { extractable }(\mathrm{g} / \mathrm{kg})\end{array}$} \\
\hline & & & & & & & & $\mathrm{Fe}$ & $\mathrm{Mn}$ & $\mathrm{Al}$ \\
\hline Paddy soil (stagnic anthrosols) & 5.55 & 2.79 & 2.17 & 22.4 & 1.84 & 8.73 & 27.6 & 8.06 & 0.15 & 1.26 \\
\hline Red soil (udic ferrosols) & 4.48 & 1.54 & 0.25 & 14.2 & 26.6 & 38.6 & 33.3 & 2.26 & 0.19 & 1.11 \\
\hline $\begin{array}{l}\text { Fluvoaquic soil (aquic } \\
\text { cambosols) }\end{array}$ & 7.91 & 0.95 & 14.2 & 10.1 & 1.54 & 7.79 & 19.4 & 0.80 & 0.10 & 0.38 \\
\hline $\begin{array}{l}\text { Fluvoaquic soil (aquic } \\
\text { cambosols) }\end{array}$ & 7.93 & 1.00 & 14.0 & 15.0 & 1.28 & 8.73 & 20.2 & 0.91 & 0.14 & 0.65 \\
\hline $\begin{array}{l}\text { Fluvoaquic soil (aquic } \\
\text { cambosols) } \\
\text { Black soil (udic isohumosols) }\end{array}$ & $\begin{array}{l}7.87 \\
6.03\end{array}$ & $\begin{array}{l}2.04 \\
6.16\end{array}$ & $\begin{array}{c}10.2 \\
3.18\end{array}$ & $\begin{array}{l}17.0 \\
35.9\end{array}$ & $\begin{array}{l}6.26 \\
3.23\end{array}$ & $\begin{array}{c}12.2 \\
9.95\end{array}$ & $\begin{array}{l}20.9 \\
27.5\end{array}$ & $\begin{array}{l}1.37 \\
5.01\end{array}$ & $\begin{array}{l}0.16 \\
0.85\end{array}$ & $\begin{array}{l}0.90 \\
2.62\end{array}$ \\
\hline
\end{tabular}

tion for predicting toxicity and making specific decisions in soil management and remediation. Thus, root elongation tests were performed with two plant species on six Chinese soils with different physicochemical properties to discover the main soil properties affecting As toxicity to plants.

\section{MATERIALS AND METHODS}

\section{Test soils}

With great differences in geographical distribution and development phases, noncontaminated soils were collected from six provinces of China, and they were air-dried and sieved through a 2-mm grid. The soil types and basic properties were determined and are presented in Table 1. Soil $\mathrm{pH}$ was measured in $0.01 \mathrm{M}$ of $\mathrm{CaCl}_{2}$ with a soil-to-water ratio of 1:2.5. Organic matter was measured using a method of hot $\mathrm{K}_{2} \mathrm{Cr}_{2} \mathrm{O}_{4}$ oxidization and $\mathrm{FeSO}_{4}$ titration [24]. Amorphous $\mathrm{Fe}$, $\mathrm{Al}$, and $\mathrm{Mn}$ oxides were extracted with ammonium oxalate [25-26] and determined with an inductively coupled plasmaoptical emission spectrometer. The content of $\mathrm{CaCO}_{3}$ was analyzed using the acid neutralization and titration methods. Cation exchange capacity was calculated by determining the $\mathrm{Na}$ concentration of the ammonium acetate $\left(\mathrm{NH}_{4} \mathrm{OAC}\right)$ extractant, which was derived by exchanging and washing the Na-saturated soil [27]. Clay content was obtained from the soil particle size distribution measured with a laser diffraction system (Malvern Master Sizer 2000) after particles diffused in a solution of $0.5 \mathrm{M}$ of $\mathrm{NaOH}$ (for soil $\mathrm{pH}<6$ ), $0.5 \mathrm{M}$ of $\mathrm{Na}_{2} \mathrm{C}_{2} \mathrm{O}_{4}$ (for soil $\mathrm{pH}=6-7.5$ ), or $0.5 \mathrm{M}$ of $\mathrm{NaPO}_{3}$ (for soil $\mathrm{pH}>7.5$ ) [28]. Total contents of soil with As and Fe were determined by an inductively coupled plasma-optical emission spectrometer after the digestion of a soil sample $(<0.25 \mathrm{~mm})$ with aqua regia at $160^{\circ} \mathrm{C}$ [21]. Chemical properties were analyzed with triplications.

Soils were spiked with different levels of arsenate $\left(\mathrm{Na}_{3} \mathrm{AsO}_{4} \cdot 12 \mathrm{H}_{2} \mathrm{O}\right.$, analytical reagent), which is recognized as the predominant form of As in aerobic soil solutions [29]. The ratio of solution to soil was settled to $20 \%(\mathrm{v} / \mathrm{m})$ according to preliminary experiments. After the spiked soil was air-dried, it was passed through the 2-mm sieve again and aged for at least 2 weeks before the root elongation test. For soils of Fengqiu, Dezhou, and Tongzhou (near Beijing), the spiked As concentration had seven levels (0, 40, 60, 90, 135, 200, and $300 \mathrm{mg} / \mathrm{kg}$ ), while soils of Jiaxing, Qiyang, and Hailun had 10 levels $(0,40,60,90,135,200,300,450,675$, and $1,000 \mathrm{mg} / \mathrm{kg}$ ). These levels were set according to preliminary results.

\section{Plant toxicity test}

Seeds of wheat (Triticum aestivum L., Zhongmai 9) and lettuce (Lactuca sativa) were purchased from the Chinese Academy of Agricultural Sciences, Beijing, China. Seeds were sterilized with $10 \%$ hydrogen peroxide for $10 \mathrm{~min}$, followed by thorough washing with deionized water. The seeds were submerged in distilled water and cultured in an incubator at $30^{\circ} \mathrm{C}$ for $24 \mathrm{~h}$. After the radicel appeared, seeds with uniform appearance were chosen for the subsequent toxicity test.

A mass of $300 \mathrm{~g}$ of soil was weighed out and transferred to a plastic cup; either 10 germinated wheat seeds or 25 lettuce seeds were then embedded just beneath the soil surface. Soil moisture was checked daily and maintained at 20\% (v/w). After growing for $6 \mathrm{~d}$, the seedlings were harvested and the main root lengths were measured. Each soil-plant-As treatment was run in triplicate.

The experiments were carried out in a growth chamber controlled with a 14:10-h light:dark photoperiod (260$350 \mu \mathrm{mol} \mathrm{m} \mathrm{m}^{-2} \mathrm{~s}^{-1}$ ), a day/night temperature of $25 / 20^{\circ} \mathrm{C}$, and a relative humidity of $70 \%$.

\section{Statistical analysis}

The no-observed-effect concentration (NOEC) value was determined by the Dunnett's program, version 1.5 (in L184), and statistical analysis was provided by the U.S. Environmental Protection Agency for biological methods (www.epa.gov/eerd/ stat2.htm). If a significant $F$ value of $p<0.05$ was obtained, Dunnett's multiple comparison versus control group analysis was conducted [30]. The median effective concentration (EC50) calculation was performed by the regression method using SigmaPlot ${ }^{\circledR} \quad 9.0$ (SPSS). A logistic formula with three parameters was chosen [31]:

$$
y=a /\left[1+\left(x / x_{0}\right)^{b}\right]
$$

Here, $y$ is the wheat root length, $x$ is the As concentration, $a$ is the expected root length when $x=0, x_{0}$ is the EC50, and $b$ is the slope parameter. A root length of $0.9 a$ is expected when $x$ is the $10 \%$ effective concentration (EC10), so EC10 could be obtained from the fitted equation. Stepwise multiple linear regressions were performed using SPSS 11.5 to identify the significant soil properties affecting As phytotoxicity.

\section{RESULTS AND DISCUSSION}

Arsenic toxicity for wheat

The root elongation tests of wheat exposed to different levels of As in six Chinese soil samples were plotted as 


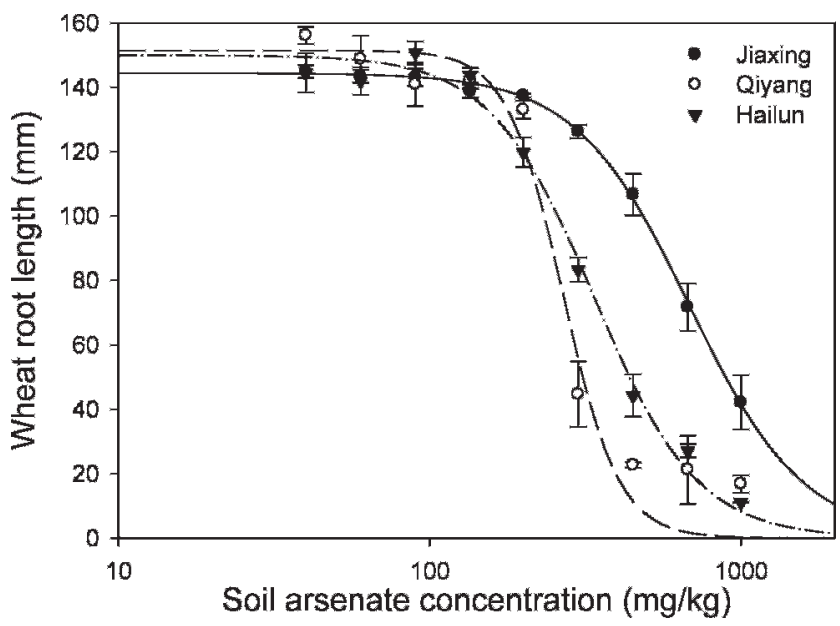

Fig. 1. Concentration-effect curves for wheat exposed to As-spiked soils of Jiaxing, Qiyang, and Hailun (China). Symbols represent mean values with standard error, and lines are fitted log-logistic curves.

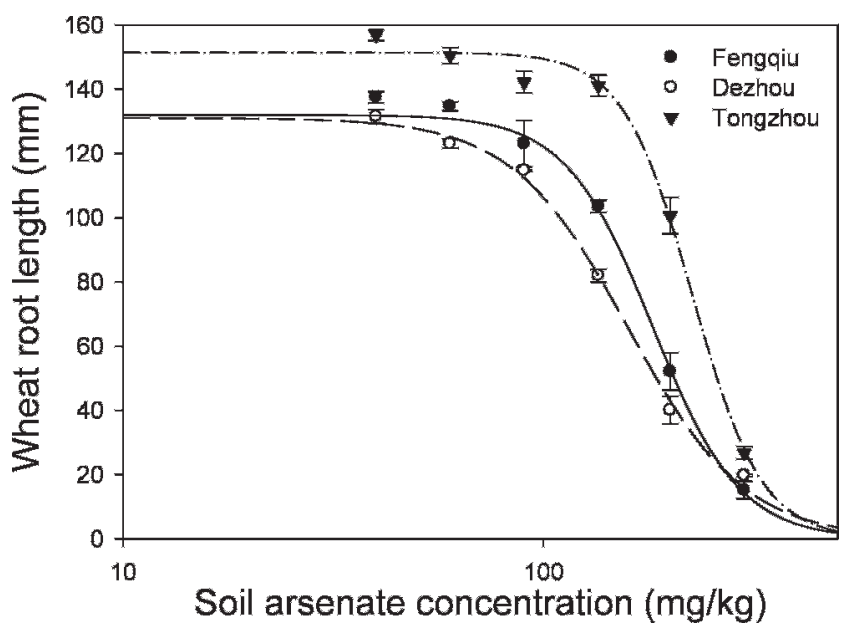

Fig. 2. Concentration-effect curves for wheat exposed to As-spiked soils of Fengqiu, Dezhou, and Tongzhou (China). Symbols represent mean values with standard error, and lines are fitted log-logistic curves.

concentration-effect curves (Figs. 1 and 2). Toxicity thresholds for wheat were calculated and are presented in Table 2. From the figures, it can be seen that different soils exhibit different toxic thresholds for As. Toxicities of As depend heavily on soil types, with a toxicity trend of fluvoaquic soil toward red soil or

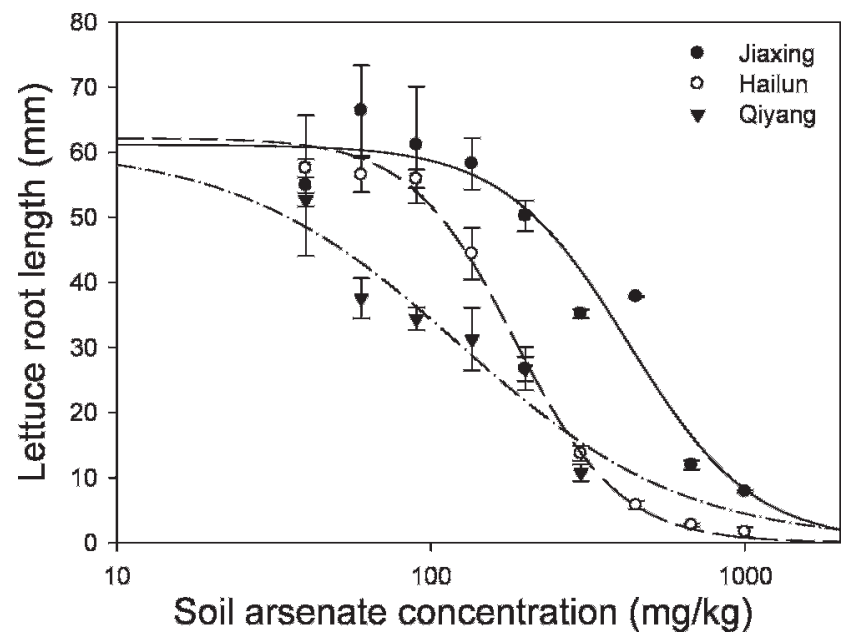

Fig. 3. Concentration-effect curves for lettuce exposed to As-spiked soils of Jiaxing, Qiyang, and Hailun (China). Symbols represent mean values with standard error, and lines are fitted log-logistic curves.

black soil toward paddy soil. The EC50 of As varied from 159 to $683 \mathrm{mg} / \mathrm{kg}$, and EC10 varied from 79 to $270 \mathrm{mg} / \mathrm{kg}$. All calculated EC10 values are close to but greater than NOEC values. Soils with higher EC50 values also had higher NOEC values.

\section{Arsenic toxicity for lettuce}

Lettuce is more sensitive than wheat to As. Concentrationeffect curves of lettuce (Figs. 3 and 4) showed a greater variation among the six soils. Arsenic toxicities are also significantly related to soil types, with the tendency of fluvoaquic soil toward red soil or black soil toward paddy soil. The EC50 values ranged from 59 to $426 \mathrm{mg} / \mathrm{kg}$, the calculated EC10 values varied from 20 to $156 \mathrm{mg} / \mathrm{kg}$. These are mostly similar to NOEC values, but some are higher than NOEC values. The higher NOEC values may be ascribed to the greater variation of root lengths between the replicates. For soils of Fengqiu and Dezhou, data of the lowest concentration $(40 \mathrm{mg} / \mathrm{kg})$ significantly differed from controls ( $0 \mathrm{mg} / \mathrm{kg}$ ), so NOEC values must be lower than $40 \mathrm{mg} / \mathrm{kg}$.

\section{Sensitivity of plants to arsenic toxicity and data comparison}

Arsenic phytotoxicity varied greatly according to plant species. The toxicity thresholds determined from the lettuce root elongation test were generally lower than those deter-

Table 2. Toxicity data of arsenate on two plant species in six Chinese soils

\begin{tabular}{|c|c|c|c|c|c|c|c|c|c|c|}
\hline \multirow[b]{2}{*}{ Site Name } & \multicolumn{5}{|c|}{ Wheat } & \multicolumn{5}{|c|}{ Lettuce } \\
\hline & $\mathrm{EC} 50^{\mathrm{a}}$ & $a$ & $b$ & $\mathrm{EC} 10^{\mathrm{b}}$ & NOEC $^{c}$ & $\mathrm{EC} 50^{\mathrm{a}}$ & $a$ & $b$ & $\mathrm{EC} 10^{\mathrm{b}}$ & $\mathrm{NOEC}^{\mathrm{c}}$ \\
\hline Jiaxing & $682.9 \pm 8.3$ & $144.4 \pm 0.7$ & $2.37 \pm 0.07$ & 270.0 & 200 & $426.5 \pm 51.1$ & $61.1 \pm 3.2$ & $2.19 \pm 0.53$ & 156.40 & 200 \\
\hline Qiyang & $268.3 \pm 17.9$ & $151.5 \pm 6.3$ & $4.84 \pm 1.34$ & 170.4 & 135 & $123.7 \pm 25.0$ & $60.8 \pm 5.0$ & $1.22 \pm 0.29$ & 20.40 & 40 \\
\hline Fengqiu & $181.7 \pm 6.4$ & $132.0 \pm 3.1$ & $4.20 \pm 0.55$ & 107.7 & 90 & $64.8 \pm 5.3$ & $71.7 \pm 4.5$ & $2.91 \pm 0.54$ & 30.47 & $<40^{\mathrm{d}}$ \\
\hline Dezhou & $159.1 \pm 4.3$ & $131.0 \pm 2.2$ & $3.13 \pm 0.23$ & 78.9 & 60 & $59.3 \pm 6.0$ & $42.9 \pm 2.7$ & $2.16 \pm 0.39$ & 21.38 & $<40^{\mathrm{d}}$ \\
\hline Tongzhou & $226.2 \pm 5.8$ & $151.4 \pm 2.6$ & $5.26 \pm 0.62$ & 149.0 & 60 & $104.3 \pm 3.4$ & $72.3 \pm 2.1$ & $5.90 \pm 0.89$ & 71.89 & 60 \\
\hline Hailun & $337.0 \pm 13.9$ & $150.0 \pm 2.9$ & $2.61 \pm 0.24$ & 145.4 & 135 & $185.5 \pm 8.9$ & $62.1 \pm 1.7$ & $2.60 \pm 0.27$ & 79.73 & 90 \\
\hline
\end{tabular}

${ }^{a}$ The As concentrations $(\mathrm{mg} / \mathrm{kg}$ ) that inhibited 50\% root elongation (median effective concentration, EC50), the expected root length in controls (a), and slope parameter $b$ were obtained by regression, with their ranges in the parentheses (mean \pm standard error).

${ }^{\mathrm{b}}$ The As concentrations $(\mathrm{mg} / \mathrm{kg})$ that inhibited $10 \%$ root elongation $(10 \%$ effective concentration, EC10) were calculated from regression equations. ${ }^{c}$ No-observed-effect concentrations (NOECs, $\mathrm{mg} / \mathrm{kg}$ ) were derived from Dunnett's test.

${ }^{\mathrm{d}}$ The lowest As addition of $40 \mathrm{mg} / \mathrm{kg}$ already produced a significant reduction in root length compared with controls, so the NOEC value will be less than $40 \mathrm{mg} / \mathrm{kg}$. 


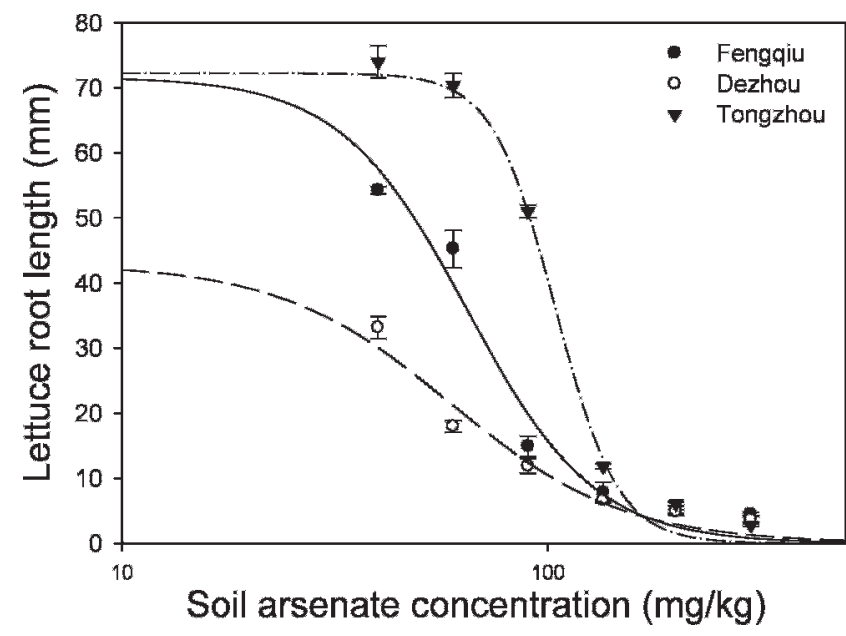

Fig. 4. Concentration-effect curves for lettuce exposed to As-spiked soils of Fengqiu, Dezhou, and Tongzhou (China). Symbols represent mean values with standard error, and lines are fitted log-logistic curves.

mined from the wheat test, indicating that lettuce is a more sensitive species. The difference in response to As may exist between species and between genotypes within one species [32].

Information is scarce on soil As toxicity to wheat and lettuce based on root elongation tests. With As concentration lower than $40 \mathrm{mg} / \mathrm{kg}$, most soils in our experiment had no significant effect on root elongation; $40 \mathrm{mg} / \mathrm{kg}$ has also been regarded as the upper limit of soil As background levels [9]. Similar results were reported by Song et al. [22], who performed a 4-d barley root elongation assay in 16 European soils and obtained EC50 values ranging from 27 to $458 \mathrm{mg} / \mathrm{kg}$ and EC10 values ranging from 4.2 to $207.0 \mathrm{mg} / \mathrm{kg}$; most of NOEC values were less than $30 \mathrm{mg} / \mathrm{kg}$.

\section{Relationships between toxicity and soil properties}

Regression analysis between plant EC $x(x=10$ or 50$)$ and soil properties was conducted (Figs. 5 and 6). Stepwise multiple linear regressions indicate that the content of ammonium oxalate extractable-Fe (Fe-ox) is the major soil property that has strong relationship with the EC50 and EC10 values. Other properties, such as $\mathrm{pH}$ and $\mathrm{CaCO}_{3}$ content, are not related to As toxicity thresholds.

Early studies have revealed that arsenate can be strongly adsorbed to iron or manganese oxides, clay, or other soil constituents at low $\mathrm{pH}$ conditions [23]. Experiments showed that iron oxide had a strong potential in reducing As availability to both wheat and lettuce. Arsenate and iron oxides may form surface complexes, and the amount of complex varies with surface coverage. This was supported by Fendorf et al. in the study of As retention to soil goethite [33]. The effect of soil amorphous iron on phytotoxicity mainly rests with As bioavailability and is reflected by the plant uptake. Warren and Alloway [34] added 0 to $1.09 \% \mathrm{FeSO}_{4}$ to soils with a $577-\mathrm{mg} / \mathrm{kg}$ As level and found that the lettuce As decreased exponentially with increasing $\mathrm{FeSO}_{4}$ concentrations. They obtained a reduction ratio of $89 \%$ compared with the control.

Soil $\mathrm{pH}$ is commonly regarded as an important factor in determining soil As toxicity [35]. However, in the present study, the relationships between $\mathrm{pH}$ and $\mathrm{EC} x$ values for all six soils are not significant.

Results from the present study indicate that As concentrations inhibiting 10 or $50 \%$ wheat and lettuce root length vary greatly for the tested soils. Among the six soils tested, the ratios of higher and lower ECx for soils are 4.3 and 3.4 for wheat and 7.2 and 7.6 for lettuce, respectively. Smith et al. [36] reviewed the data on soil As toxicity to plants and found that
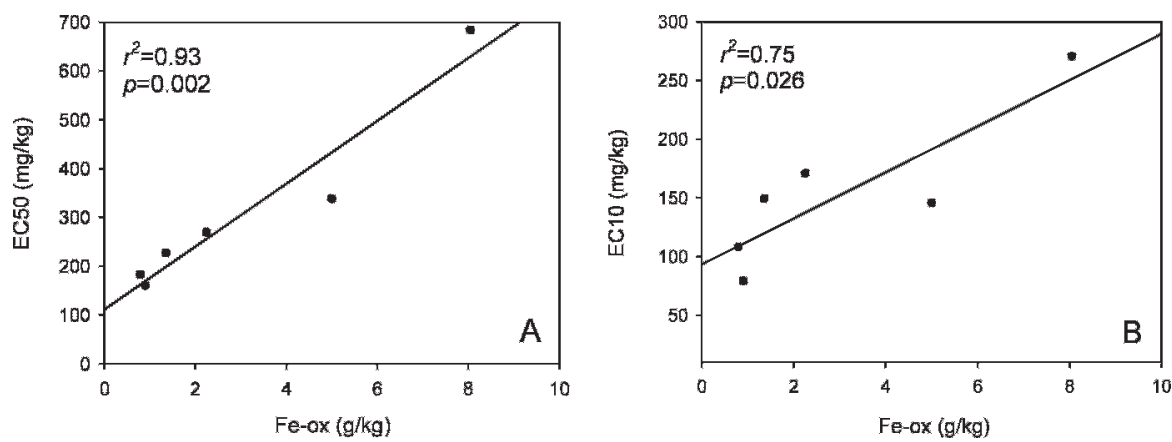

Fig. 5. Correlation between As toxicity data and soil contents of Fe-ox (ammonium oxalate extractable-Fe): median effective concentration and Feox (A), and 10\% effective concentration and Fe-ox (B). Wheat root elongation in $6 \mathrm{~d}$ as a toxicological test endpoint.
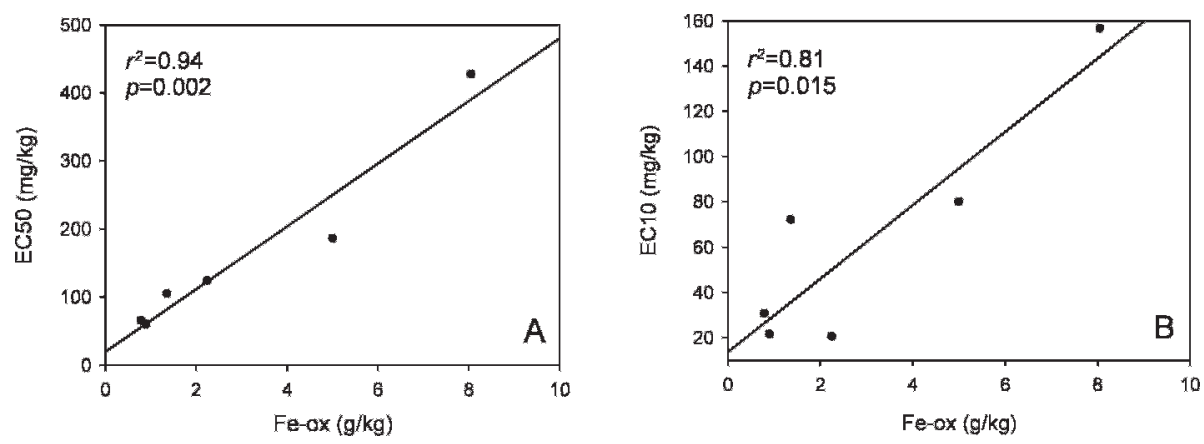

Fig. 6. Correlation between As toxicity data and contents of Fe-ox (ammonium oxalate extractable-Fe) contents: median effective concentration and $\mathrm{Fe}-\mathrm{ox}(\mathbf{A})$, and 10\% effective concentration and Fe-ox (B). Lettuce root elongation in $6 \mathrm{~d}$ as a toxicological test endpoint. 
As toxicity thresholds were five times more toxic to plants grown in sandy soils (mean $40 \mathrm{mg} / \mathrm{kg}$ ) than in clayey soils (mean $200 \mathrm{mg} / \mathrm{kg}$ ). This conclusion was not confirmed in the present study by regression analysis between plant EC $x$ and soil texture data.

In general, As bioavailability, plant uptake, and phytotoxicity are expected to vary with soil properties, especially the contents of iron oxides. Other properties, such as $\mathrm{pH}$, clay minerals, and organic matter, whether they had effects or not, are soil specific. For a given As application level, the As phytotoxicity variation with test plants and soils suggests that site-specific conditions should be taken into consideration for the soil environmental assessment.

\section{CONCLUSION}

Phytotoxicity of arsenate in soil varies greatly according to test species and soil types. With lower toxic thresholds for As, lettuce is more sensitive than wheat and could be used as a sensitive biomonitor. Amorphous iron content affects the As toxicity, but other soil properties such as $\mathrm{pH}$ and $\mathrm{CaCO}_{3}$ content did not influence As toxicity in the present experiment. The site-specific soil characteristics should be taken into account in soil environmental management and remediation judgment.

Acknowledgement-The present study was supported by the Ministry of Science and Technology of China (2002CB410808), the Natural Science Foundation of China (40321101) and Chinese Academy of Sciences (KZCX3-SW-431).

\section{REFERENCES}

1. Frazer L. 2005. Metal attraction: An ironclad solution to arsenic contamination? Environ Health Perspect 113:398-401.

2. Sun GF, Li X, Pi JB, Sun Y, Li B, Jin, YP, Xu YY. 2006. Current research problems of chronic arsenicosis in China. $J$ Health Popul Nutr 24:176-181.

3. Agency for Toxic Substances and Disease Registry. 2007. Toxicological profile for arsenic. U.S. Department of Health and Human Services, Public Health Service, Atlanta, GA, USA.

4. Liao XY, Chen TB, Xie H, Liu YR. 2005. Soil As contamination and its risk assessment in areas near the industrial districts of Chenzhou City, Southern China. Environ Int 31:791-798.

5. Liu XL, Zhang SZ, Shan XQ, Zhu YG. 2005. Toxicity of arsenate and arsenite on germination, seedling growth and amylolytic activity of wheat. Chemosphere 61:293-301.

6. Patra M, Bhowmik N, Bandopadhyay B, Sharma A. 2004. Comparison of mercury, lead and arsenic with respect to genotoxic effects on plant systems and the development of genetic tolerance. Environ Exp Bot 52:199-223.

7. U.S. Environmental Protection Agency. 1998. Integrated risk information system (IRIS): Arsenic, inorganic. CASRN 7440-38-2. Cincinnati, $\mathrm{OH}$

8. U.S. Environmental Protection Agency. 2001. National primary drinking water regulations: Arsenic and clarifications to compliance and new source contaminants monitoring, Final Rule. 40 CFR Parts 9, 141, and 142. Fed Reg 66:6976-7066.

9. World Health Organization. 2001. Environmental health criteria 224. Arsenic and arsenic compounds, 2nd ed. Geneva, Switzerland.

10. Department for Environment Food and Rural Affairs. 2002. Soil guideline values for arsenic contamination. Environmental Agency, Bristol, UK.

11. International Organization for Standardization. 1999. Soil quality: Inhibition of reproduction of Collembola (Folsomia candida) by soil pollutants. Guideline 11267. Geneva, Switzerland.

12. Organisation for Economic Co-operation and Development. 1984. Earthworm: Acute toxicity tests. Guideline 207. Paris, France.
13. Organisation for Economic Co-operation and Development. 2004. Earthworm reproduction test (Eisenia fetidalEisenia andrei). Guideline 222. Paris, France.

14. Organisation for Economic Co-operation and Development. 2004. Enchytraeid reproduction test. Guideline 220. Paris, France.

15. American Society for Testing and Materials. 2004. Standard guide for conducting laboratory soil toxicity or bioaccumulation tests with the Lumbricid earthworm Eisenia fetida and the Enchytraeid potworm Enchytraeus albidus. E 1676-04. West Conshohacken, PA.

16. Organisation for Economic Co-operation and Development. 2000. Soil microorganisms: Nitrogen transformation test. Guideline 216. Paris, France.

17. Organisation for Economic Co-operation and Development. 2000. Soil microorganisms: Carbon transformation test. Guideline 217 Paris, France.

18. Organisation for Economic Co-operation and Development. 1984. Terrestrial plants: Growth test. Guideline 208. Paris, France.

19. Clark J, Ortego LS, Fairbrother A. 2004. Sources of variability in plant toxicity testing. Chemosphere 57:1599-1612.

20. Chaturvedi I. 2006. Effects of arsenic concentration and forms on growth and arsenic uptake and accumulation by Indian mustard (Brassica juncea L.) genotypes. J Cent Eur Agr 7:31-40.

21. Tang XY, Zhu YG, Shan XQ, McLaren R, Duan J. 2007. The ageing effect on the bioaccessibility and fractionation of arsenic in soils from China. Chemosphere 66:1183-1190.

22. Song J, Zhao FJ, McGrath FP, Luo YM. 2006. Influence of soil properties and aging on arsenic phytotoxicity. Environ Toxicol Chem 25:1663-1670.

23. Juhasz AL, Naidu R, Zhu YG, Wang LS, Jiang JY, Cao ZH. 2003. Toxicity issues associated with geogenic arsenic in the groundwater-soil-plant-human continuum. Bull Environ Contam Toxicol 71:1100-1107.

24. Nelson DW, Sommers LE. 1996. Total carbon, organic carbon, and organic matter. In Bartels JM, ed, Methods of Soil Analysis, Part 3-Chemical Methods. Soil Science Society of America and American Society of Agronomy. Madison, WI, pp 961-1010.

25. Shuman LM. 1982. Separating soil iron oxide and manganese oxide fractions for microelement analysis. Soil Sci Soc Am J 46: 1099-1102.

26. Rodriguez RR, Basta NT, Casteel SW, Armstrong FP, Ward DC. 2003. Chemical extraction methods to assess bioavailable arsenic in soil and solid media. J Environ Qual 32:876-884.

27. Ming DW, Dixon JB. 1987. Quantitative determination of clinoptilolite in soils by a cation-exchange capacity method. Clays Clay Miner 35:463-468.

28. Bittelli M, Campbell GS, Flury M. 1999. Characterization of particle-size distribution in soils with a fragmentation model. Soil Sci Soc Am J 63:782-788.

29. De Brouwere K, Smolders E, Merckx R. 2004. Soil properties affecting solid-liquid distribution of $\mathrm{As}(\mathrm{V})$ in soils. Eur $J$ Soil $S c i$ 55:165-173.

30. Dunnett CW. 1955. A multiple comparison procedure for comparing several treatments with a control. J Am Stat Assoc 50:1096-1121.

31. Jensen J, Sverdrup LE. 2002. Joint toxicity of linear alkylbenzene sulfonates and pyrene on Folsomia fimetaria. Ecotoxicol Environ Saf 52:75-81.

32. Geng CN, Zhu YG, Tong YP, Smith SE, Smith MA. 2006. Arsenate (As) uptake by and distribution in two cultivars of winter wheat (Triticum aestivum L.). Chemosphere 62:608-615.

33. Fendorf S, Eick MJ, Grossl P, Sparks DL. 1997. Arsenate and chromate retention mechanisms on goethite. 1. Surface structure. Environ Sci Technol 31:315-320.

34. Warren GP, Alloway BJ. 2003. Reduction of arsenic uptake by lettuce with ferrous applied to contaminated soil. J Environ Qual 32:767-772.

35. Yang JK, Barnett MO, Jardine PM, Basta NT, Casteel SW. 2002 Adsorption, sequestration, and bioaccessibility of $\mathrm{As}(\mathrm{V})$ in soils. Environ Sci Technol 36:4562-4569.

36. Smith E, Naidu R, Alston AM. 1998. Arsenic in the soil environment: A review. Adv Agron 64:149-195. 